\title{
Ho Chi Minh's thought on Foreign and Its Implications for Vietnam's Foreign Policy Today
}

Huynh Tuan Linh ${ }^{*}$

Post-Graduate in University of Social Sciences and Humanities - Vietnam National University Ho Chi Minh City and Teaching at Ho Chi Minh City Food Industry University, 140 Lê Trọng Tấn, Tây Thạnh, Tân Phú, Hồ Chí Minh, Vietnam

DOI: $10.36348 /$ jaep.2020.v04i07.003

| Received: 02.07.2020 | Accepted: 09.07.2020 | Published: 12.07 .2020

*Corresponding author: Huynh Tuan Linh

\section{Abstract}

This study focuses on analyzing Ho Chi Minh's thought on foreign affairs that is a problem very important in Ho Chi Minh's thought. This study indicated that it was Ho Chi Minh's flexible but sharp foreign policy that helped the state Democratic Republic of Vietnam, which was born after 1945 maintained its was independence and enlist the help of allied nations and peace-loving forces in the world. This study shows that this thought has great significance for Vietnam's foreign policy today. That thought has become a valuable lesson for Vietnam when participating in international foreign affairs in the period of globalization of international economic integration.

Keywords: Ho Chi Minh's thought on foreign, Vietnam's foreign policy, Communist Party of Vietnam, Socialist Republic of Vietnam.

Copyright @ 2020: This is an open-access article distributed under the terms of the Creative Commons Attribution license which permits unrestricted use, distribution, and reproduction in any medium for non-commercial use (NonCommercial, or CC-BY-NC) provided the original author and sources are credited.

\section{INTRODUCTION}

President Ho Chi Minh was a great leader of the Communist Party and people of Vietnam, a prominent soldier of the communist movement, international workers, and the national liberation movement, outstanding cultural celebrity of world. His revolutionary life and career left behind a wealth of invaluable reasoning, revolutionary ideas, and science.

Ho Chi Minh's thought is a product of application process and development of MarxistLeninist creations in the context of Vietnamese revolution; is the succession and development of the nation's good traditional values, the acquisition of the quintessence of human culture and the system of comprehensive and profound views on the basic issues of the Vietnamese revolution. Ho Chi Minh's thought on foreign affairs is an integral part of his revolutionary ideological system, which includes his system of international perspectives and the forms, measures, and behaviors of art in international relations to serve the revolutionary career in each period. Ho Chi Minh's thought in foreign affairs is very broad and profound, which can be exploited from many different angles. This is an extremely important theoretical and practical matter, demonstrating the revolutionary and scientific nature, theory, and practice in his thoughts.
His ideas have always been the guiding principle for the Vietnamese revolution in general and diplomacy in particular, developing step by step raising Vietnam's position in the international arena. Stemming from the meaning of the above issue, the article delves into the content of Ho Chi Minh's thought on foreign affairs and its meaning to Vietnam's foreign policy today.

\section{LITERATURE REVIEW}

Foreign lines and diplomacy policy is an important part of the political lines system of the Vietnamese revolution. The reality of the history of the nation's struggle for national construction and defense shows that only when the Communist Party of Vietnam was born can there be a complete and truly revolutionary political path. In that system of political lines, foreign policy is an important part to serve the political policy in general.

The first foreign policy of our country was built by Ho Chi Minh in "The way of Revolutionary" 1927, "Brief policy" 1930 [1]. It was then mentioned in a 4-point system of foreign policy in the Viet Minh program before the General uprising (1944), then adopted by the Tan Trao National Conference (August 1945). Particularly, the views on foreign policy were expressed by Ho Chi Minh in the Declaration of 
Independence (September 2, 1945) and through the report on the foreign policy of the state Democratic Republic of Vietnam (October 3, 1945) [2]. In the documents of the Communist Party of Vietnam always consider the foreign policy as an important part of the system of policies of our Party built by Ho Chi Minh, showing the views of the true proletariat. Not stopping there, Ho Chi Minh also considered the diplomatic front as an important weapon, allow us to change the correlation of forces that benefit us, unfavorable to the enemy. While explaining how to fight by cunning, Ho Chi Minh pointed out: "Using the best soldiers is fighting with tactics. The second is fighting with diplomacy. The third is fighting with soldiers".

These basic ideological views of Ho Chi Minh have been demonstrated in the Vietnamese revolutionary practice through a consistent, objective and scientific political system; passed through the National Party Congresses in the revolutionary period, which is the basis for the development of Vietnamese diplomacy.

\section{RESEARCH CONTENT}

Independence of sovereignty in foreign affairs is one of the standards and prerequisites for ensuring true national independence

The sovereignty and independence of the nation is the premise to build independent autonomy and sovereignty to have its own diplomacy. On the contrary, having autonomy diplomacy is the standard to assert the true independence of the nation.

After the successful August revolution (1945) as President of the Government and Foreign Minister, Ho Chi Minh persisted in the struggle to build and protect the nation's diplomacy. That origin is an important factor to complete the nation's independence. Ho Chi Minh pointed out: if the Vietnamese army and diplomacy are under French rule, Vietnam is not fully independent and still a French colony; at the same time, Ho Chi Minh also asserted that: independence means that we control all our work, without outside interference. This thought of Ho Chi Minh is not only a legitimate aspiration of all nations but has become a standard in modern international relations.

After the Preliminary Agreement (March 6, 1946) [2], Vietnam's basic national rights were recognized, but the issue of "independent diplomacy" still had to be fought because France had not yet agreed. On the other hand, Ho Chi Minh argued that independence and sovereignty of diplomacy are the premises for the implementation of equality and democracy rights among ethnic nations in international life.

Thus, Ho Chi Minh's thought on independent diplomacy is not dependent on the outside, which is an important ideological foundation of the new
Vietnamese diplomacy. This condition is even more important in the trend of globalization in all areas of human life today.

Foreign policy is independent, self-help for selfimprovement, while expanding international relations

Based on the standpoint of independent diplomacy, without outside intervention, Ho Chi Minh considered this a standard to guarantee a nation's true independence. It must not only stop at nominal diplomacy but must be intrinsic, showing the forms, steps, measures of behavior in international relations on the basis of independence, autonomy and self-reliance, reliance.

For a long time, Ho Chi Minh often advised that "to liberate us by our own power", He considered the independence and resilience to be the "root", "the key point" of all policies, the modes and the sources of motivation to develop the country $[1,2]$. Ho Chi Minh affirmed that domestic resources are decisive, international advantages are important, but the proactive choice is the form and measure in international relations based on our own potential "people, for example, the Vietnamese people have to devise their own methods and measures" [1]

Ho Chi Minh also pointed out that independence and self-reliance in diplomacy do not stop at proactively planning policies and measures, but it is more important to know to actively exploit internal resources in the spirit of self-reliance. On the other hand, self-reliance, resilience is not synonymous with closed, isolated but enhanced international relations. He once pointed out that one of the reasons for the decline of the eastern peoples in isolation. Ho Chi Minh also considered that the Vietnamese revolution is part of the world revolution, closely associated with the revolutionary movement and progress in the world for peace, national independence, and social progress.

Ho Chi Minh's thought on self-reliance and resilience at the same time expanded international cooperation, combining national strength with the tested era and the Communist Party of Vietnam considered this a lesson of success merit of Vietnam.

Consistently on the goal of national independence and socialism, but flexible, creative, flexible, and concessions in principle

Consistent with the strategic principle, creativity, flexibility, and flexibility in strategy is Ho Chi Minh's diplomatic art. Independence, freedom, national unity, building socialism for the prosperity and happiness of the people are the basic and long-term goal. That is "The invariant" to "deal with all the change" with appropriate guidelines, measures, and forms. This thought of Ho Chi Minh shows that diplomacy is both scientific and artistic; the art of Uncle 
Ho's diplomatic activities was formed on the basis of scientific thinking about the world with analyzes and forecasts for optimal foreign policy. The art of diplomacy manifests itself in the following ways:

Predicting the world situation, when France surrendered to Germany, Ho Chi Minh left Europe to go to China to lead the Vietnamese Revolution, who predicted the victory to success, in 1945. When Japan couped the French in Indochina, President Ho Chi Minh issued a directive "Japan and France to shoot each other and our actions" (March 12, 1945) and prepare the General uprising [2]. When there was news that Japan was about to surrender, the Allies were about to enter Indochina to disarm the Japanese weapons. He declared to the world of Vietnam independence and determination to protect freedom and national independence, etc.

Knowing to win step by step towards complete victory, after the success of the revolution 1945, the revolutionary government encountered many difficulties, had to fight enemies in the outside to preserve the revolutionary results. The "preliminary treaty" (March 6, 1946) was the basis for the later Geneva Agreement of 1954 and the 1973 Paris Agreement.

The flexibility in gathering forces, adding friends, reducing enemies to create a world front for the anti-enemy. During the anti-French resistance war against the American, not only the progressive people in the world supported us, but Ho Chi Minh also distinguished the French and American imperialists from the progressive French working people and the progressive American people by thanks for the help of neighboring countries in the region. Ho Chi Minh advocated building strategic solidarity with Laos and Cambodia, enlisting the support of China, establishing relations with Thailand, India, Myanmar, Indonesia, etc.

\section{Applying Ho Chi Minh's thought on diplomacy in the current period of Vietnam}

In the period of renovation and international integration, we have achieved success step by step with joining ASEAN in 1995, joining regional and global organizations, such as the Asia-Europe Cooperation Forum ASEM, 1996, Asia-Pacific Economic Cooperation Forum APEC, 1998, World Trade Organization WTO, 2006, gradually integrating deeply into the regional and world economy with participation in negotiations and signing of free trade agreements (FTA), etc [3, 4].

New developments and breakthroughs in foreign policy in the renovation period: Innovation in foreign thinking. Resolution No. 13 of the Politburo (Session VI) in May 1988 initiated the process of renewing the Party's foreign thinking with the task of actively shifting the struggle from a confrontation state to a struggle and cooperation in peace coexist. In June 1992, the Resolution of the 3rd plenum of the Party Central Committee set out a policy of expansion, multilateralization, and diversification of foreign relations, marking the formation of the foreign policy of our Party in the renovation period [5, 6]. In each period, the foreign policy of Vietnam during the "renovate" period excellently performed its tasks: breaking the siege, isolation (1986-1996); expand cooperation and promote international economic integration (19962006); integrate international relations in depth and comprehensive international integration (from 2006 to present) with new breakthroughs and developments, such as:

Firstly, clearly defining priorities of national and ethnic interests; maintain independence and autonomy; diversify, multilateralism relations. The renewal period marked an important turning point with the determination of national and national interests in the new context, putting development goals at the top of the development target while firmly assisting the goal of ensuring national security and international position. The major task of foreign affairs in this period was to "maintain a peaceful and favorable environment for accelerating industrialization and modernization; firmly defend independence, sovereignty, unity and territorial integrity; empower the country; contribute positively to the struggle for peace, national independence, democracy and social progress in the world [7]".

Maintaining national and national interests, in the context of integration, autonomy and, autonomy is the interaction to have the right to participate in making decisions on regional and international issues and the ability to use resources external forces to solve national problems. Independent autonomy is also a prerequisite for effective integration. Besides, independence and autonomy are also a premise for diversification and multilateralization; Diversification and diversification are an effective way to maintain independence and autonomy, especially as our country increasingly integrates into the world in a comprehensive and profound manner in a complex and changing international environment.

Second, being a reliable partner, responsible members; bring international relations in depth; proactively and actively integrate internationally. The identification of Vietnam "as a friend, a reliable partner and responsible member in the international community" [8], "international integration" in a comprehensive way, as well as deepening national relations Our country's economy has shown important changes in the Party's foreign thinking, in accordance with changes in the situation of the country and the world. Implementing foreign policy in this direction will enhance the prestige, international position, gather forces, and mobilize the support and sympathy of the 
international community in addressing security and development issues development.

In addition, the strategic foundation for our foreign affairs in the context of complicated international and regional environment will be strengthened, in the direction of deepening international relations and opening up broadening the implications of partnerships, increasing the degree of intermingling of interests, especially strategic interests, long-term economic benefits with partners; consolidate and create cooperation mechanisms to ensure the stability and sustainability of the relationship, gradually increasing political trust [6].

In the process of deep integration into the global and regional "playing field", Vietnam actively participates in developing general rules and codes of conduct in international relations in line with national interests, development forces, and levels of the country in international integration. The Politburo's Resolution No. 22-NQ/TW (April 10, 2013) on international integration has made strategic directions, unified awareness, clarified objectives, directive views, and contents basics of international integration in the fields, major solutions, and orientations to implement in the coming time.

Thirdly, new thinking about security in dealing with partnerships - objects. The 3rd plenum of the 7 th Plenum 1992 clearly defined the guideline for dealing with foreign affairs to master both sides of cooperation and struggle in international relations. By the 8th Plenum of the 9th Conference 2003, this view was developed and further concretized, giving a dialectical view of the relational object, giving the concept of "object" (fighting paintings) and "partners" (cooperation) and a flexible view of these concepts.

This is an important breakthrough in thinking to create common awareness in strengthening cooperative relations with most countries in the world, including countries that are having problems with our country. In addition to innovating in the selection of relational objects, the new motto of "partners and subjects" also helps us to improve our determination to foster relationships and innovations in determining the form and content of relations with countries.

During the "renovate" period, our new security thinking has emphasized the dependence on the security of other countries in the region and the importance of ensuring the external environment adjacent to Vietnam peace and stability orientation, orientation for foreign priority to Southeast Asian countries. The credo of national construction during the transition to socialism (addition, development in 2011) affirms, "striving with countries of the Association of Southeast Asian Nations (ASEAN) to build Southeast Asia into a region of peace, stability, cooperation, and prosperous development" $[9,10]$. The priority of ASEAN cooperation is a step of higher development in thinking, with clearly affirming that Vietnam is an active, active and responsible member in ASEAN, striving with member countries to build building a strong ASEAN Community, having close relationships with external partners, playing an increasingly important role in regional cooperation mechanisms.

\section{CONCLUSION}

In an increasingly complex international environment, foreign affairs have contributed effectively to firmly protecting the sovereignty and territorial integrity of the Fatherland. We have endeavored to build a border of peace, friendship, and development with Laos, Cambodia, and China. In the face of the complexities in the East Sea, we have appreciated the situation, struggled, dealt with promptly, alert, lucid, resolute, steadfastly defending sovereignty, territorial integrity, and rights and the legitimate interests of Vietnam at the sea.

In addition to the above results, the pillars and other important areas of foreign affairs have achieved many achievements. External relations of the Party, State diplomacy, People's foreign affairs, National Assembly's foreign affairs, defense-security foreign affairs have been implemented effectively, closely and smoothly coordinated; Economic diplomacy, cultural diplomacy, protection of Vietnamese citizens and foreign affairs, and foreign information have been actively and actively implemented, making important contributions to the common external achievements of the land country.

On the sidelines of the third decade of the 21st century, the world is witnessing great, profound, and unpredictable fluctuations. Peace, cooperation, and development are still major trends, but the Covid-19 pandemic has contributed to accelerating the profound changes in the international context, directly affecting the security and development environment of the country our country. We need to continue to creatively apply Ho Chi Minh's diplomatic ideology to put Vietnam in the right "flow of the times", creating great strength to bring the Vietnamese revolution to new victories.

Accordingly, Vietnam's diplomacy needs to promote its role as a "front" in order to firmly consolidate a favorable international environment and attract resources to serve the country's development and position, defending the country early, from afar, from the time the country is not at risk. The "arms" of Vietnam's foreign affairs, including State diplomacy, Party diplomacy, and people's external relations, need to work together to take advantage of new opportunities and effectively handle the complex challenges currently in place out. We need to apply well the principle of "constant invariants, universal variables". It is 
necessary to insist on the constant goal of the nation's ultimate benefit with the meaning of peace, independence, sovereignty, territorial integrity, and enhancement of the nation's strength and position; at the same time, flexible and skillful in strategy and action to handle the "universal variables" of the situation. In the face of complications in the East Sea, we persistently use peaceful means to resolve disputes, and "resolutely fight to the end to protect the most sacred rights: Territorial integrity for the Fatherland" and independence for the country".

\section{REFERENCE}

1. Ho Chi Minh. (2000). The complete episode, episode 2. Hanoi: National politics.

2. Ho Chi Minh. (2011). The Complete episode, episode 4. Hanoi: National Politics.

3. Communist Party of Vietnam. (2000). Complete Party Document, episode 7. Hanoi: National Politics.

4. Ministry of Foreign Affairs. (2008). Uncle Ho and diplomatic activities - Some memories of Uncle Ho. Hanoi: National politics.
5. Communist Party of Vietnam. (2000). The Complete Party Document episode 8. Hanoi: National politics.

6. Nguyen, M. H. (2006). Consistent implementation of the foreign policy of independence, peace, cooperation, and development. Journal of Communism 12:23-31.

7. Vu Khoan. (1993). Security, Development, and Influence in Foreign Affairs. International Studies 2:3-11.

8. Communist Party of Vietnam. (2011). The platform for building the country during the transition to socialism (Supplement, development in 2011). Hanoi: National politics.

9. Communist Party of Vietnam. (2011). Document of the 11th National Party Congress. Hanoi: National politics.

10. Communist Party of Vietnam. (2016). Document of the 12th National Party Congress. Hanoi: National politics. 